Jurnal IImiah AL-Jauhari (JIAJ)

Volume 4 No 1, (Juni 2019): 172-193

p-ISSN: $2541-3430$

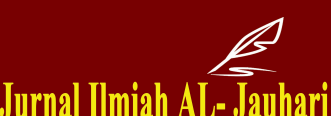

e-ISSN: 2541-3449

Website: http://journal.iaingorontalo.ac.id/index.php/aj

\title{
Implikasi Teknologi Informasi Komunikasi terhadap Prestasi Belajar Peserta Didik pada Kelompok Mata Pelajaran Agama
}

\author{
Sarton Abdullah, Arten Mobonggi, \\ Najamuddin Petta Solong, Muh. Arif \\ (IAIN Sultan Amai Gorontalo) \\ sartonabdullah1@,gmail.com, artenmobonggi@yahoo.com, \\ uddinpettasolong@gmail.com, muharif@iaingorontalo.ac.id
}

\begin{abstract}
This article aims to reveal the implications of Information and Communication Technology on the learning achievement of students in the Religious Education subject group at Muhammadiyah High School in Gorontalo, using qualitative methods with a descriptive approach. The results showed that making ICT-based learning media with topics contained in the syllabus and lesson plans with due regard to the value of competency standards. The Qur'anic Hadith teacher and the history of Islamic culture have not used much but many motivate learning to students through material presentation. The implications of ICT on the learning achievements of fiqh students and moral aqidahs that use power points and digital teaching materials have not had an impact on learning achievement because they are not adjusted to the learning styles of students and are not accompanied by motivation from teachers and sometimes abusing ICT use for something which is not expected by the teacher. While the teacher of the Qur'an's Hadith and History of Islamic Culture, despite the lack of use of ICT in learning, is balanced by giving motivation when presenting material and ease of learning.
\end{abstract}

\begin{abstract}
Abstrak
Artikel ini bertujuan mengungkap adanya implikasi TIK terhadap prestasi belajar peserta didik pada kelompok mata pelajaran Pendidikan Agama di MA Muhammadiyah Gorontalo, dengan
\end{abstract}


menggunakan metode kualitatif dengan pendekatan deskriptif. Hasil penelitian menunjukkan bahwa pembuatan media pembelajaran berbasis TIK dengan topik yang terdapat pada silabus dan RPP dengan memperhatikan nilai standar kompetensi. Adapun guru Qur'an Hadis dan SKI belum banyak menggunakannya namun banyak memotivasi belajar kepada peserta didik melalui penyajian materi. Implikasi TIK terhadap prestasi belajar peserta didik fikih dan akidah akhlak yang menggunakan power point dan bahan ajar digital belum memberikan dampak terhadap presasi belajar karena kurang disesuaikan dengan gaya belajar peserta didik dan tidak dibarengi dengan pemberian motivasi dari guru serta terkadang peserta didik menyalahgunakan penggunaan TIK untuk sesuatu yang tidak diharapkan oleh guru. Sedangkan guru Qur'an Hadis dan SKI kendati kurang menggunakan TIK dalam pembelajaran namun diimbangi dengan pemberian motivasi ketika menyajikan materi dan terjadi kemudahan belajar.

Kata Kunci: Teknologi; Komunikasi; Prestasi Belajar;

\section{Pendahuluan}

Dengan memperhatikan kegiatan-kegiatan yang dilakukan oleh seorang guru pada saat menyajikan bahan ajar kepada para peserta didiknya. Guru pada umumnya sering menggunakan media pembelajaran dengan tujuan agar informasi atau bahan ajar tersebut dapat diterima dan diserap dengan baik oleh para peserta didik. Sebagai wujud bahwa bahan ajar tersebut dapat diterima oleh peserta didik dibuktikan dengan terjadinya perubahan-perubahan perilaku baik berupa pengetahuan, sikap, maupun keterampilan.

Di negara-negara maju pemanfaatan teknologi informasi dan komunikasi sudah menyatu dalam kehidupan masyarakat sehingga secara mandiri mereka dapat memperoleh informasi yang diperlukannya untuk menambah ilmu pengetahuannya. Teknologi informasi dan komunikasi merupakan sarana yang menyediakan sumber ilmu pengetahuan yang tidak habis-habisnya untuk digali dan dimanfaatkan oleh yang membutuhkannya.

Indonesia di era dunia maya (cyberworld) telah menjadi bagian penting dari sistem komunikasi dan informasi global. Milenium III di awal abad 21, sebuah fenomena berupa kian meluasnya globalisasi yang melibatkan semua aspek kehidupan umat manusia. Tidak ada lagi negara atau bangsa yang sanggup meluputkan diri dari globalisasi. Dunia telah menjadi sebuah dusun (global village). ${ }^{1}$

Implikasi yang sedemikian luas tersebut telah memberikan warna atau wajah baru dalam sistem pendidikan dunia, yang dikenal dengan berbagai istilah e-learning, distance learning, online learning,

\footnotetext{
${ }^{1}$ Andi Abdul Muis, Indonesia di Era Dunia Maya: Teknologi Informasi dalam Dunia Tanpa Batas (Cet. 1; Bandung: Remaja Rosdakarya, 2001), h. 3.
} 
web based learning, computer-based learning, dan virtual class room, di mana semua terminologi tersebut mengacu pada pengertian yang sama yakni pendidikan berbasis teknologi informasi. ${ }^{2}$

Terkait dengan hal ini pemerintah Indonesia sudah termasuk cepat dalam menanggapi kebutuhan dunia pendidikan terhadap TIK. Sebagai contoh, pada pendidikan tinggi (kampus), ketersediaan internet kini semakin meluas, mulai tersedia teknologi video conference, yang semuanya itu memberikan penguatan pada proses pembelajaran di sekolah/madrasah. Sementara itu, tingkat keefektifan pembelajaran di sekolah salah satunya dipengaruhi oleh kemampuan guru menerapkan asas kekonkretan dalam mengelola proses pembelajaran. Untuk mewujudkan asas kekonkretan dalam pembelajaran di sekolah dibutuhkan adanya media pembelajaran yang tepat. $^{3}$

Observasi awal sekaligus wawancara singkat dengan salah satu informan sekaligus mantan kepala madrasah ${ }^{4}$ mengenai teknologi informasi komunikasi di lokasi tersebut sesuai maupun informasi guru setempat bahwa penggunaan media komputer sebagai penunjang pembelajaran namun baru hanya disesuaikan dengan materi yang disajikan sehingga tidak memperhatikan aspek karakteristik peserta didik, kurang dibarengi pemberian motivasi, tidak diperoleh kemudahan belajar yang berimplikasi pada capaian prestasi belajarnya.

Kenyataan yang ada di lapangan saat ini, tidak sedikit peserta didik yang belum menyadari pentingnya media ini dalam meningkatkan prestasi belajar. Data di lapangan menyebutkan bahwa MA Muhammadiyah Kota Gorontalo mempunyai 1 laboratorium dengan memiliki 25 komputer yang terkoneksi internet. Lebih dari $95 \%$ peserta didik telah menggunakan komputer. Teknologi ini mereka gunakan sekadar mengisi waktu luang saja bahkan ada yang kesulitan dalam pelaksanaan proses pembelajaran yang up date melalui penggunaan TIK pada proses pembelajaran.

Hasil pengamatan lainnya bahwa penggunaan teknologi komunikasi dan informasi di MA Muhammadiyah Kota Gorontalo dengan menggunakan media-media komunikasi seperti telepon, komputer, dan internet. Namun interaksi antara guru dan peserta didik masih lebih dominan dilakukan melalui hubungan tatap muka dan kurang memanfaatkan media-media tersebut. Guru kurang memberikan layanan tanpa harus berhadapan langsung dengan peserta didik untuk memperoleh informasi dalam lingkup yang luas dari berbagai sumber melalui ruang maya dengan menggunakan komputer

\footnotetext{
${ }^{2}$ Kementerian Agama Republik Indonesia, Modul Pengembangan TIK, h. 322.

${ }^{3}$ Benny A. Pribadi Andayani, Panduan Praktek Pembuatan Media dan Pemanfaatan Komputer, (Jakarta: UT, 2008), h. 1.

${ }^{4}$ Romy Bau, Kepala MA Muhammadiyah Kota Gorontalo, wawancara, tanggal 9 Februari 2018.
} 
atau internet.

Hal lain yang ditemukan di lapangan adalah implikasi dari penggunaan TIK bagi peserta didik adalah prestasi belajarnya yang terkadang menurun pada mata pelajaran tertentu karena banyak ditemukan konten yang negatif di internet sehingga menjadikan fokus perhatiannya beralih dari belajar menjadi bermain game on line dan mengamati konten negatif dalam bentuk gambar dan vidio yang tidak layak dilihat oleh peserta didik.

\section{Hakikat Teknologi Informasi dan Komunikasi}

Teknologi Informasi Komunikasi merupakan salah satu terobosan dari dunia pendidikan dalam peningkatan pemanfaatan tekhnologi informasi yang tidak bisa dipisahkan dengan dunia informasi tekhnologi sekarang, sering dikenal dengan digital devide atau teknologi digital teknologi yang menggunakan dan memanfaatan internet sebagai sarana tempat pembelajaran dan menggunakan fasilitas web yang tersedia disitus dari sebuah organisasi atau pun institusi pendidikan.

Teknologi Informasi dan Komunikasi mencakup dua aspek, yaitu Teknologi Informasi dan Teknologi Komunikasi. Teknologi Informasi, meliputi segala hal yang berkaitan dengan proses, penggunaan sebagai alat bantu, manipulasi, dan pengelolaan informasi. Sedangkan Teknologi Komunikasi merupakan segala hal yang berkaitan dengan penggunaan alat bantu untuk memproses dan mentransfer data dari perangkat yang satu ke lainnya. Oleh karena itu, Teknologi Informasi dan Teknologi Komunikasi adalah suatu padanan yang tidak terpisahkan yang mengandung pengertian luas tentang segala kegiatan yang terkait dengan pemrosesan, manipulasi, pengelolaan, dan transfer/pemindahan informasi antar media. ${ }^{5}$

TIK merupakan payung besar terminologi yang mencakup seluruh peralatan teknis untuk memproses dan menyampaikan informasi. Teknologi secara garis besar dibagi menjadi dua, yaitu teknologi informasi dan teknologi komunikasi. Sehinga peralatan teknologi informasi dan komunikasi akan sedikit berbeda, walupun secara garis besar sama.

Menurut Puskur Diknas Indonesia TIK mencakup dua aspek, yaitu Teknologi Informasi dan Teknologi Komunikasi: (a) Teknologi Informasi dan Teknologi Komunikasi adalah suatu padanan yang tidak terpisahkan yang mengandung pengertian luas tentang segala kegiatan yang terkait dengan pemrosesan, manipulasi, pengelolaan, dan transfer/pemindahan informasi antar media. (b) Teknologi Komunikasi adalah segala hal yang berkaitan dengan penggunaan alat bantu untuk memproses dan mentransfer data dari perangkat yang satu ke lainnya. ${ }^{6}$

${ }^{5}$ Munir, Kurikulum Berbasis Teknologi Informasi dan Komunikasi, (Bandung: Alfabeta, 2008), h. 5.

${ }^{6}$ Ibid., h. 6. 
Jadi dapat ditegaskan bahwa seorang guru yang kompeten ialah seorang guru yang mempunyai seperangkat pengetahuan, keahlian dan keterampilan yang diperoleh melalui pendidikan dan pelatihan dan diwujudkan dengan sertifikat sebagai pengakuan yang diberikan kepada guru sebagai tenaga yang profesional.

Pemanfaatan TIK yang baru di sekolah merupakan suatu padanan tidak terpisahkan yang mengandung pengertian luas tentang segala aspek terkait dengan pemrosesan, manipulasi, pengelolaan, dan transfer (pemindahan) informasi antar media menggunakan teknologi tertentu yang menekankan peserta didik mampu memahami konsep, pengetahuan, dan operasi dasar komputer.

Penjelasan di atas, dapat disimpulkan bahwa TIK sangat mempengaruhi pembelajaran, dalam hal ini yaitu tujuan yang ingin dicapai dalam pembelajaran karena salah satu syarat tercapainya suatu pendidikan adalah peningkatan sumber daya manusia, oleh karena itu dalam dunia pendidikan pemanfaatan media yang sesuai dengan perkembangan zaman sangat diperlukan.

Kaitan dengan ini, dengan berkembangnya pemanfaatan TIK ada lima pergeseran dalam proses pembelajaran yaitu: dari pelatihan ke penampilan, dari ruang kelas ke di mana dan kapan saja, dari kertas ke online atau saluran, fasilitas fisik ke fasilitas jaringan kerja, dan dari waktu siklus ke waktu nyata.

Jadi dapat disimpulkan bahwa TIK sangat penting untuk membangkitkan motivasi belajar peserta didik, karena dengan adanya media maka akan membuat peserta didik ikut aktif dalam pembelajaran. Bukan hanya sekedar guru yang aktif di dalamnya. Dengan TIK peserta didik bisa belajar kapan saja dan di mana saja, tidak bergantung pada ruang saja. Sehingga memungkinkan peserta didik untuk berekspresi tanpa adanya tekanan dari guru.

TIK adalah media yang mencakup semua teknologi yang dapat digunakan untuk menyimpan, mengolah, menampilkan, dan menyampaikan informasi dalam proses komunikasi. Yang termasuk teknologi ini adalah: (a) Teknologi komputer, baik perangkat keras (hardware) maupun perangkat lunak (software) pendukungnya. Di dalamnya termasuk prosesor (pengolah data), media penyimpan data/informasi (hard disk, CD, DVD, flash disk, memori, kartu memori, dll.), alat perekam (CD Writer, DVD Writer), alat input (keyboard, mouse, scanner, kamera, dll.), dan alat output (layar monitor, printer, proyektor LCD, speaker, dll.). (b) Teknologi multimedia, seperti kamera digital, kamera video, player suara, player video, dll. (c) Teknologi telekomunikasi, telepon, telepon seluler, faksimail. (d) Teknologi jaringan komputer, baik perangkat keras (LAN, Internet, WiFI, dll.), maupun perangkat lunak pendukungnya

\footnotetext{
${ }^{7}$ Ibid., h. 200.

${ }^{8}$ http://elhafidhoh.edublogs.org/makalah-TIK/ diakses 23 November 2017 jam 10.13
} 
(aplikasi jaringan) seperti Web, e-mail, HTML, Java, PHP, aplikasi basis data, dan lain-lain. ${ }^{9}$

Jaringan komputer dalam hal ini telah banyak diterapkan di seluruh dunia, salah satunya yang paling modern saat ini adalah konsep e-learning atau konsep pembelajaran jarak jauh, di mana antara guru atau dosen dan peserta didik/mahasiswa bisa melakukan kegiatan pembelajaran di luar sekolah atau kampus.

Dari uraian di atas dapat dilihat bahwa terdapat beberapa jenis media TIK yang dapat dimanfaatkan oleh guru dalam pembelajaran karena media tersebut sangat penting untuk meningkatkan prestasi belajar peserta didik, karena dengan adanya pemanfaatan TIK dalam pembelajaran maka akan membuat peserta didik ikut aktif dan mudah belajar sehingga tujuan pembelajaran tercapai yang ditunjukkan oleh prestasi belajar peserta didik.

1. Hakikat Prestasi Belajar

Prestasi belajar adalah sebuah kalimat yang terdiri dari dua kata, yakni prestasi dan belajar. Antara prestasi dan belajar mempunyai arti yang berbeda. Sebelum penulis membahas pengertian prestasi belajar, maka penulis akan memberikan pengertian prestasi dan belajar. Langkah ini bertujuan untuk memudahkan dalam memahami lebih mendalam tentang pengertian tersebut.

Prestasi belajar terdiri dari dua kata yang mempunyai pengertian sendiri-sendiri yakni prestasi dan belajar, tetapi dalam pembahasan ini kedua kata tersebut sangat berhubungan. Prestasi adalah hasil yang telah dicapai dari suatu usaha yang telah dikerjakan. $^{11}$

Prestasi berasal dari kata prestatie bahasa Belanda yang berarti "hasil usaha". Jadi prestasi belajar merupakan hasil usaha belajar. Menurut Nasru Harahap prestasi adalah penilaian pendidikan tentang perkembangan dan kemajuan murid yang berkenaan dengan penguasaan bahan pelajaran yang disajikan kepada mereka serta nilainilai yang terdapat dalam kurikulum. Sedangkan Menurut Djamarah prestasi adalah hasil dari suatu kegiatan yang telah dikerjakan, dan diciptakan, baik secara individual maupun kelompok. ${ }^{13}$

Dari pengertian prestasi di atas, mempunyai inti yang sama yaitu hasil yang dicapai dari suatu kegiatan. Dengan demikian, dapat diambil pengertian yang cukup sederhana mengenai hal ini, yakni sebagaimana dikemukakan oleh Djamarah bahwa prestasi belajar adalah hasil yang diperoleh berupa kesan-kesan yang mengakibatkan

\footnotetext{
${ }^{9}$ Elang, op.cit., h.25.

${ }^{10}$ Azhar Arsyad, Media Pembelajaran (revisi-16-Jakarta: Rajawali Pres, 2017), h.194-199.

${ }^{11}$ Departemen Pendidikan Nasional, Kamus Besar Bahasa Indonesia, (Jakarta: Balai Pustaka, 2003), h. 895.

${ }^{12}$ Zainal Arifin, Evaluasi Instruksional Prinsip Teknik Prosedur, (Bandung: Remaja Karya, 1988), h. 123.

${ }^{13}$ Syaiful Bahri Djamarah, op. cit., h. 19
} 
perubahan dalam diri individu sebagai hasil dari aktivitas dalam belajar yang sesuai dengan nilai-nilai Islam.

Prestasi tidak akan pernah dihasilkan selama seseorang tidak melakukan suatu kegiatan. Dari kegiatan yang digeluti maka seseorang mendapatkan prestasi. Dalam hal ini berhasil atau gagalnya tujuan belajar adalah terletak pada dirinya sendiri maka dirinya sendirilah yang bertanggung jawab untuk melakukan kegiatan belajar agar berhasil. Suatu proses usaha yang dilakukan untuk memperoleh suatu perubahan tingkah laku yang baru secara keseluruhan, sebagai hasil pengalamannya sendiri dalam interaksi dengan lingkungannya disebut dengan belajar.

Hamalik belajar adalah modifikasi atau memperteguh kelakuan melalui pengalaman ${ }^{14}$. Jadi, belajar adalah suatu aktivitas yang dilakukan secara sadar untuk mendapatkan sejumlah kesan dari bahan yang telah dipelajari. Dengan kata lain, belajar merupakan suatu usaha yang dilakukan individu untuk memperoleh perubahan tingkah laku sebagai hasil pengalaman individu dalam interaksi dengan lingkungannya baik ranah kognitif, afektif maupun psikomotorik.

Prestasi belajar merupakan hasil yang diperoleh peserta didik setelah melalui beberapa proses belajar untuk mengetahui sesuatu yang belum diketahuinya, dan hanya dengan belajar maka akan dapat mengetahui, mengerti, dan memahami sesuatu dengan baik. Prestasi belajar adalah hasil yang diberikan oleh guru kepada peserta didik dalam jangka waktu tertentu sebagai hasil perbuatan belajar. ${ }^{15}$

Prestasi belajar sebagai lambang pemuas hasrat ingin tahu. Hal ini didasarkan atas asumsi bahwa para ahli psikologi biasanya menyebutkan hal ini sebagai tendensi keingintahuan dan merupakan kebutuhan umum pada manusia, termasuk kebutuhan peserta didik di dalam suatu program pendidikan. ${ }^{16}$ Prestasi adalah hasil yang dicapai seseorang ketika mengerjakan tugas atau kegiatan terterntu". Menurut Arifin "Prestasi didefinisikan sebagai kemampuan, keterampilan, dan sikap seseorang dalam menyelesaikan sesuatu hal". ${ }^{18}$

Jadi prestasi belajar adalah "Istilah yang telah dicapai individu sebagai usaha yang dialami secara langsung serta merupakn aktivitas yang bertujuan untuk memperoleh ilmu pengetahuan, ketrampilan, kecerdasan, kecakapan dan sebagainya dalam keadaan kondisi serta

\footnotetext{
${ }^{14}$ Oemar Hamalik, Proses Belajar Mengajar, (Jakarta: Bumi Aksara, 2004), h. 27.

15 Sri Estuti Wuryani, Psikologi Pendidikan, (Jakarta: Gramedia Widiasarana, 2002), h. 408.

${ }^{16}$ Abraham Maslow, Motivasi dan Kepribadian, (Jakarta: Lembaga Manajemen, 2004), h. 62.

${ }^{17}$ Tulus Tu'u, Peran Disiplin pada Perilaku dan Prestasi Peserta Didik ,(Jakarta: Grasindo, 2004), h. 75.

18 Zainal Arifin, Evaluasi Instruksional: Prinsip-Teknik-Prosedur, (Bandung: Remaja Rosdakarya, 2000), h. 3.
} 
situasi tertentu"19 Prestasi belajar adalah penguasaan pengetahuan atau keterampilan yang dikembangkan oleh mata pelajaran, lazimnya ditunjukkan dengan nilai tes atau angka nilai yang diberikan oleh guru.

Prestasi belajar merupakan hasil yang telah dicapai oleh peserta didik dalam proses pembelajaran yang ditunjukkan dengan nilai tes atau angka dari hasil evaluasi yang dilakukan oleg guru. Jadi prestasi belajar peserta didik terfokus pada nilai atau angka yang dicapai peserta didik dalam proses pembelajaran di sekolah. Nilai tersebut terutama dilihat dari aspek kognitifnya, karena aspek ini yang sering dinilai oleh guru untuk mengetahui penguasaan pengetahuan yang dijadikan sebagai ukuran pencapaian prestasi belajar peserta didik.

Pengertian tingkat prestasi belajar adalah mutu yang terdapat dalam penilaian hasil usaha kegiatan belajar yang telah dilakukan oleh manusia secara sadar dalam mengajarkan, membimbing, melatih, membina, dan mendidik menuju kesempurnaan serta kedewasaan dalam hidup dan kehidupan. Yang dinyatakan dalam bentuk simbol, angka, huruf maupun kalimat yang dapat mencerminkan hasil yang sudah dicapai oleh setiap peserta didik dalam periode tertentu.

Tingkat prestasi peserta didik secara umum dapat dilihat pencapian (penguasaan) peserta didik terhadap materi pembelajaran. Apabila bahan pelajaran yang diajarkan kurang dari $65 \%$ yang dikuasai oleh peserta didik peserta didik maka persentase keberhasilan peserta didik pada mata pelajaran tersebut tergolong rendah. ${ }^{20}$

Pada prinsipnya pengungkapan hasil belajar ideal meliputi segenap ranah psikologis yang berubah sebagai akibat pengalaman dan proses belajar peserta didik. Namun demikian, pengungkapan perubahan tingkah laku seluruh ranah itu, khususnya ranah rasa peserta didik sangat sulit. Hal ini disebabkan perubahan hasil belajar itu ada yang bersifat intangible (tak dapat diraba). ${ }^{21}$

Jadi diperlukan kegiatan evaluasi menyeluruh, berkelanjutan dan berkelanjutan obyektif. Guru hendaknya mampu membantu setiap peserta didik untuk secara efektif dapat mempergunakan berbagai kesempatan belajar dan berbagai sumber serta media belajar, hal ini berarti bahwa guru hendaknya dapat mengembangkan cara dan kebiasaan belajar yang sebaik-baiknya. Selanjutnya sangat diharapkan guru dapat memberikan fasilitas yang memadai sehingga peserta didik dapat belajar secara efektif.

\section{Realitas TIK dalam Pembelajaran pada Kelompok Mata Pelajaran Agama di MA Muhammadiyah}

\footnotetext{
${ }^{19}$ Sunaryo, Strategi Belajar Mengajar dalam Pembelajaran IPS, (Jakarta: Depdikbud, 2000), h. 298.

${ }^{20}$ Syaiful Bahri Djamarah dan Aswan Zain, Guru dan Anak Didik dalam Interaksi Edukatif, (Jakarta: Rineka Cipta, 2000), h. 18.

${ }^{21}$ Muhibbin Syah, Psikologi Belajar, (Jakarta: Raja Grafindo Persada, 2003), h. 213.
} 
Teknologi komunikasi adalah penggunaan teknologi sebagai media dalam komunikasi manusia. Penggunaan teknologi sebagai media dalam komunikasi ini banyak dipengaruhi oleh perkembanganperkembangan teknologi dari ilmu pengetahuan lainnya. Pembelajaran pada kelompok mata pelajaran Pendidikan Agama di madrasah. Kelompok mata pelajaran pendidikan agama terdiri atas akidah akhlak, al-Qur'an Hadis, fikih, dan SKI dapat dipahami sebagai suatu program pendidikan yang menanamkan nilai-nilai Islam melalui proses pembelajaran, baik di kelas maupun di luar kelas yang dikemas dalam bentuk mata pelajaran dan diberikan dengan menggunakan media TIK.

Pengamatan penulis dalam pembelajaran kelompok mata pelajaran pendidikan agama masih ada guru yang belum memanfaatkan peralatan teknologi informasi dan komunikasi di sekolah, hal ini disebabkan karena belum terampil menggunakan alatalat teknologi informasi dan komunikasi tersebut, tetapi secara umum guru kelompok mata pelajaran pendidikan agama telah mampu dan terampil menggunakan TIK dalam proses pembelajaran di kelas.

Pemanfaatan alat teknologi informasi dan komunikasi (TIK) di MA Muhammadiyah Kota Gorontalo tidak ada model yang baku, tetapi diserahkan kepada guru masing-masing mata pelajaran untuk memanfaatkan peralatan teknologi informasi dan komunikasi dalam pembelajaran.

Hasil penelitian ternyata realitas TIK dalam pembelajaran terkesan bahwa aktivitas guru dan peserta didik dalam hal ini tampaknya cenderung didominasi oleh kegiatan yang berpusat pada guru (teacher oriented). Kendati demikian guru telah berupaya agar tetap memberikan aktivitas yang menekankan pada kegiatan yang berpusat pada guru dan peserta didik. Perangkat pembelajaran (Silabus, RPP, Materi/buku modul peserta didik dan guru, slide presentation, LKS) yang semula didominasi dengan penyajian secara langsung, maka setelah direvisi penyajiannya menjadi penggabungan yang berimbang antara penyajian langsung dengan pengkonstruksian oleh peserta didik dengan media internet terhadap materi pembelajaran pada kelompok mata pelajaran pendidikan agama.

Keefektifan pembelajaran dengan menggunakan TIK pada kelompok mata pelajaran pendidikan agama ditentukan oleh empat hal, yaitu ketuntasan klasikal, aktivitas peserta didik, kemampuan guru mengelola pembelajaran, dan respons peserta didik terhadap pembelajaran dengan TIK.

Terkait dengan keefektifan penggunaan TIK dalam pembelajaran kelompok mata pelajaran pendidikan agama penulis tampilkan hasil pengamatan dalam bentuk tabel berikut ini:

Tabel: 1

Hasil Pengamatan Keefektifan Penggunaan TIK dalam Pembelajaran Akidah Akhlak dan Fikih di MA Muhammadiyah Kota Gorontalo

\begin{tabular}{ccccc}
\hline No & Aspek Diamati & \multicolumn{3}{c}{ Hasil Pengamatan } \\
\hline 1 & Ketuntasan & Gembira & menerima materi dan \\
\hline
\end{tabular}




\begin{tabular}{llll}
\hline & Klasikal & \multicolumn{2}{l}{ aktivitas belajar } \\
\hline 2 & $\begin{array}{l}\text { Aktivitas } \\
\text { Didik }\end{array}$ & Peserta & $\begin{array}{l}\text { Antusias dengan adanya slide } \\
\text { presentasion }\end{array}$ \\
\hline 3 & Kemampuan Guru & Penguasaan TIK belum merata \\
\hline 4 & $\begin{array}{l}\text { Respons } \\
\text { Didik }\end{array}$ & Peserta & $\begin{array}{l}\text { Tertarik menerima materi dan uji } \\
\text { kompetensi }\end{array}$ \\
\hline
\end{tabular}

Sumber Data: Lembar Pengamatan, 2018

Hasil-hasil yang diperoleh terkait dengan keefektifan pembelajaran dengan menggunakan TIK tersebut menunjukkan adanya kesesuaian dengan hasil-hasil yang terkait kepraktisan dari TIK pada kelompok mata pelajaran pendidikan agama. Pada pengamatan di atas tampak secara umum sudah baik namun pada aspek respons peserta didik dan kemampuan guru belum sepenuhnya optimal karena disebabkan pembelajaran dengan menggunakan TIK terdapat guru dan peserta didik yang baru pertama kali menerapkan media tertentu seperti LCD dan media komputer.

Hal ini diakui oleh guru Qur'an Hadis bahwa selama pembelajaran lebih banyak tidak menggunakan media disebabkan oleh kesulitan dalam mengoperasionalkannya dan membuat power point menjadi hambatan dengan kemampuan yang masih terbatas sehingga lebih baik tidak menggunakan media apalagi jika menuliskannya dalam bahasa Arab. ${ }^{22}$

Pernyataan yang sama dikemukakan oleh peserta didik bahwa masih terdapat guru kelompok mata pelajaran pendidikan agama yang kurang menggunakan media dalam pembelajaran yakni guru alQur'an Hadis dan Sejarah Kebudayaan Islam. Sedangkan guru yang sering menggunakannya adalah guru akidah akhlak dan fikih. Guru yang sering menggunakan media dalam pembelajaran lebih mudah dipahami dan tidak membosankan peserta didik yang belajar dari pada yang tidak menggunakan media. ${ }^{23}$

Pernyataan di atas dapat dipahami karena di era digital saat ini orang semakin sadar dan merasakan akan pentingnya media dalam rangka membantu dalam proses pembelajaran. Karena pada hakikatnya proses belajar adalah proses komunikasi (proses penyampain pesan) yang harus diwujudkan melalui kegiatan penyampaian dan tukar menukar pesan atau informasi oleh setiap guru dan peserta didik.

Untuk menguatkan hasil penelusuran di atas penulis melakukan pengumpulan dokumen pada masing-masing mata pelajaran yang menggunakan TIK dalam pembelajarannya. Dokumentasi yang penulis lakukan terkait dengan masing-masing mata pelajaran dalam penggunaan TIK dan ketuntasan belajar yang

\footnotetext{
November 2018.

${ }^{23}$ Abdullah Pagari, Peserta Didik MA Muhammadiyah Kota Gorontalo, 2 November 2018.
}

${ }^{22}$ Aji Alfalah, Guru Qur'an Hadis MA Muhammadiyah Kota Gorontalo, 2 
ditunjukkan pada dokumen dimaksud yang dapat dilihat pada tabel berikut ini:

Tabel: 2

Dokumentasi TIK dan Ketuntasan Belajar pada Mata Pelajaran Akidah Akhlak Semester Ganjil Kelas X MA Muhammadiyah Kota Gorontalo

\begin{tabular}{clccc}
\hline No & Pokok Bahasan & TIK & KKM & $\begin{array}{c}\text { Rata-Rata } \\
\text { Kelas }\end{array}$ \\
\hline 1 & Pengertian Akidah & Power Point & 75 & 80 \\
\hline 2 & Pengertian Tauhid & Power Point & 75 & 82 \\
\hline 3 & Pengertian Akhlak & Power Point & 75 & 85 \\
\hline 4 & $\begin{array}{l}\text { Induk-Induk } \\
\text { Akhlak Terpuji }\end{array}$ & Smart Binner & 75 & 83 \\
\hline 5 & $\begin{array}{l}\text { Induk-Induk } \\
\text { Akhlak Tercela }\end{array}$ & Power Point & 75 & 85 \\
\hline 6 & $\begin{array}{l}\text { Adab kepada } \\
\text { Orang Tua dan } \\
\text { Guru }\end{array}$ & Power Point & 75 & 85 \\
\hline 7 & $\begin{array}{l}\text { Pembiasaan, } \\
\text { Syukur, Qanaah, } \\
\text { Ridho, dan Sabar }\end{array}$ & - & 75 & 82 \\
\hline 8 & $\begin{array}{l}\text { Meneladani Kisah } \\
\text { Nabi Yusuf }\end{array}$ & - & 75 & 85 \\
\hline
\end{tabular}

Sumber Data: Dokumentasi Penelitian, 2018

Dari data dokumentasi di atas terlihat bahwa mata pelajaran akidah akhlak pada semester ganjil kelas $X$ terdapat delapan pokok bahasan dan rata-rata KKM untuk setiap pokok bahasan adalah 75 . Penggunaan TIK dalam pembelajaran akidah akhlak tampaknya belum disesuaikan dengan gaya belajar peserta didik yakni auditif, visual, dan kinestetik. Hal ini ditunjukkan oleh jenis media yang digunakan belum beragam dan lebih cenderung pada media visual berupa power point sehingga menjadikan kejenuhan bagi peserta didik yang memiliki gaya belajar auditif dan kinestetik.

Padahal secara teoretis bahwa gaya belajar adalah cara orang belajar menyerap dan mengolah informasi untuk mencapai keberhasilan dalam belajar, gaya belajar inilah yang tampaknya menjadi kunci keberhasilan dalam menyerap dan mengolah informasi yang pada akhirnya akan menetukan kinerja seseorang baik di dunia persekolahan, dunia kerja atau dalam hubungan antar pribadi peserta didik dalam pembelajaran. ${ }^{24}$

Diakui oleh guru bahwa untuk menciptakan proses pembelajaran yang berhasil dengan baik, peserta didik diajak untuk memanfaatkan semua alat inderanya. Guru berupaya menampilkan rangsangan atau stimulus yang dapat di proses dengan berbagai

\footnotetext{
${ }^{24}$ Bob Samples, Revolusi Belajar Untuk Anak, (Bandung: Kaifa, 2015), h. 20.

182 | Sarton Abdullah, Arten Mobonggi, Najamuddin Petta Solong, Muh. Arif
} 
indera. Semakin banyak alat indera yang digunakan untuk menerima dan mengolah informasi semakin besar kemungkinan informasi tersebut dimengerti dan dapat dipertahankan dalam ingatan. Dengan demikian, pserta didik diharapkan akan dapat menerima dan menyerap dengan mudah dan baik pesan-pesan dalam materi yang disajikan.

Peserta didik pun mengakui bahwa belajar dengan menggunakan indera ganda, pandang dan dengar telah memberikan keuntungan baginya dalam menerina materi melalui media teknologi dan informasi. Menurutnya, belajar lebih banyak daripada jika materi pelajaran disajikan hanya dengan stimulus pandang atau hanya dengan stimulus dengar karena memberikan kemudahan baginya dalam belajar. $^{26}$

Guru akidah akhlak mengakui bahwa dalam proses belajar yang dilakukan antara pendidik dengan peserta didik di kelas memiliki kecendrungan gaya belajar yang berbeda-beda, perlu dipahami bahawa peserta didik akan lebih berhasil, jika guru menyesuaikan strategi dan media yang digunakan dengan gaya belajar individual peserta didik. Akan tetapi kesulitannya adalah dalam menentukan gaya belajar sehingga cenderung diabaikan dalam pemilihan media TIK dalam pembelajaran di kelas sehingga diakuinya terkadang masih menimbulkan kejenuhan. ${ }^{27}$

Dari pengamatan penulis, terdapat 5 unsur penting dalam proses pembelajaran di MA Muhammadiyah Kota Gorontalo yaitu guru atau pendidik bertugas sebagai penyampai ilmu, motivator dan pembimbing. Peserta didik merupakan objek sekaligus subjek untuk mencapai tujuan di dalam proses pembelajaran. Ilmu bagian yang harus diserap dan diketahui oleh peserta didik yang disampaikan melalui media TIK. Nilai adalah hak yang diberikan guru untuk peserta didik sesuai kondisi melalui penciptaan suasana dan pembudayaan. Media Teknologi yang berguna sebagai sarana canggih untuk membantu proses pembelajaran. Mata pelajaran fikih pada semester ganjil kelas $\mathrm{X}$ terdapat lima pokok bahasan dan rata-rata KKM untuk setiap pokok bahasan adalah 70. Penggunaan TIK dalam pembelajaran fikih tampaknya sedikit lebih baik dibandingkan dengan guru akidah akhlak karena sudah disesuaikan dengan gaya belajar peserta didik yakni auditif, visual, dan kinestetik. Hal ini ditunjukkan oleh jenis media yang digunakan dalam setiap pertemuan sudah beragam yakni lebih dari satu jenis media dan lebih cenderung pada media visual dan audio berupa power point, LCD dan CD pembelajaran sehingga memberikan rangsangan dan kemudahan bagi peserta didik yang menerima materi. Hanya saja yang menimbulkan

\footnotetext{
${ }^{25}$ Noho Husin Nusa, Guru Akidah Akhlak MA Muhammadiyah Kota Gorontalo, Wawancara, 2 November 2018.

${ }^{26}$ Luthfiah Nur Abidah Maulana, Peserta Didik MA Muhammadiyah Kota Gorontalo, Wawancara, 2 November 2018.

${ }^{27}$ Fitri Salilama, Kepala MA Muhammadiyah Kota Gorontalo, Wawancara, 2 November 2018.
} 
tanda tanya adalah pada nilai capaian rata-rata kelas masih belum sesuai harapan kendatipun sudah melewati KKM.

Selain kemampuan guru dalam menggunakan media belajar seperti TIK yang harus disiapkan oleh guru adalah gaya belajar peserta didik sebagai dasar dalam penggunaan TIK dalam pembelajaran. Dari peserta didik pun haruslah meyiapkan dirinya untuk proses belajar atau sebelum menerima materi dari pendidik, di antaranya gaya belajar karena gaya belajar akan ikut mengsukseskan keberhasilan dari belajar itu sendiri di antaranya gaya belajar visual, audio, dan kinestetik.

Pada penilaian kinerja guru terkait dengan kompetensi 5 terdapat dua aspek kompetensi yang masih belum sesuai harapan yakni guru dapat mengidentifikasi dengan benar tentang bakat, minat, potensi, dan kesulitan belajar masing-masing peserta didik dan guru memberikan kesempatan belajar kepada peserta didik sesuai dengan cara belajarnya masing-masing diperoleh skor 1 atau belum terpenuhi seluruhnya atau masih sebagian sehingga dalam penggunaan TIK belum optimal sebagaimana yang diharapkan.

Penggunaan TIK dalam proses pembelajaran tampaknya membantu guru dalam mentransfer materi dengan mudah kepada peserta didiknya, hanya saja belum menunjukkan kemampuan guru dalam mengidentifikasi dengan benar tentang bakat, minat, potensi, dan kesulitan belajar masing-masing peserta didik dan guru memberikan kesempatan belajar kepada peserta didik sesuai dengan cara belajarnya masing-masing karena masih diperoleh skor 1 atau terpenuhi sebagian dalam data format penilaian kinerja guru.

Pengamatan penulis menunjukkan bahwa guru fikih dalam mengajar belum mengindentifikasi dengan benar kesulitan belajar dan potensi yang dimiliki peserta didik. Sedangkan untuk bakat dan minat tampaknya sudah mampu diidentifikasi dengan benar oleh guru fikih. Adapun pada aspek lainnya yaitu guru belum memberikan kesempatan kepada peserta didik untuk belajar sesuai dengan cara belajarnya masing-masing karena lebih banyak dilakukan pembelajaran secara klasikal dengan menggunakan media yang tidak beragam.

Sehubungan dengan penggunaan media teknologi, di lapangan masih ditemukan dua orang guru yakni guru mata pelajaran al-Qur'an dan SKI yang masih belum menerapkan TIK dan masih menggunakan metode dan model-model belajar klasik seperti ceramah dan penugasan, padahal perkembangan zaman mayoritas dikuasai oleh teknologi, sudah waktunya untuk dimanfaatkan media teknologi ini sebagai media belajar dengan harapan perserta didik mampu dan tidak kaku menghadapi perkembangan zaman.

Hal ini diakui oleh guru al-Qur'an Hadis bahwa dalam mengajar sulit menyesuaikan dengan teknologi pembelajaran karena keterbatasan kemampuan dalam penggunaannya sehingga cenderung lebih aman jika menghindari atau tidak menggunakan dalam 
pembelajaran dari pada terjadi kesalahan atau kesulitan dalam menerapkannya kepada peserta didik. ${ }^{28}$

Diakui oleh kepala madrasah bahwa dengan penggunaan media teknologi seperti komputer tampaknya peserta didik lebih mudah menyerap informasi secara cepat dan efisien. Penggunaan media seperti komputer telah digunakan dalam proses pembelajaran dihampir semua bidang ilmu, begitu juga pada kelompok mata pelajaran pendidikan agama yakni terdapat dua orang guru yang sering menggunakannya. Kedua guru tersebut memberikan materi pembelajaran dengan media teknologi karena memiliki kompetensi dalam pengembangan pembelajaran walaupun diakuinya belum memberikan implikasi terhadap prestasi belajar peserta didik. ${ }^{29}$

Hanya saja jika dibandingkan dengn guru lainnya, tampaknya guru fikih dan akidah akhlak terlihat mampu bersaing dan mengembangkan keahliannya dengan penggunaan TIK khususnya komputer. Dalam penggunaan media komputer sebagai alat bantu pembelajaran kelompok mata pelajaran pendidikan agama menggunakan program Microsoft Office Powerpoint dan materi digital khususnya dalam mengerjakan tugas yang diberikan oleh guru.

Dalam menampilkan presentasi pembelajaran terkesan kurang kreatif dan membosankan baik dari segi penyajian, diskusi, komponen isi dan tampilan slide. Penggunaan Microsoft Office Powerpoint dan materi digital terkadang kurang menarik, terkadang membosankan karena tidak diikuti oleh pemberian motivasi serta media yang digunakan tidak disesuaikan dengan gaya belajar peserta didik. Hal ini menyebabkan capaian prestasi belajar peserta didik pada mata pelajaran fikih dan akidah akhlak yang tidak memberikan implikasi karena sama saja baik menggunakan media teknologi maupun tidak. ${ }^{30}$

Dari uraian di atas dapat disimpulkan bahwa pemanfaatan TIK dalam pembelajaran pada kelompok mata pelajaran pendidikan agama secara umum yaitu dengan menggunakan media PowerPoint dan bahan ajar digital. Pembuatan media pembelajaran berbasis TIK dengan topik-topik yang terdapat pada silabus dan RPP mata pelajaran akidah akhlak dan fikih dengan menggunakan PowerPoint dirancang berdasarkan RPP akidah akhlak dan fikih yang digunakan untuk peserta didik dengan memperhatikan nilai standar kompetensi. Perancangan bahan ajar digital menggunakan aplikasi SOM (Screen Cast Omatic) yang sangat interaktif. Pembelajaran fikih dan akidah akhlak menggunakan PowerPoint dan bahan ajar digital belum memberikan dampak yang positif terhadap prestasi belajar peserta didik karena kurang disesuaikan dengan gaya belajar peserta didik dan tidak dibarengi dengan pemberian motivasi dari guru.

\footnotetext{
${ }^{28}$ Aji Alfalah, Guru Qur'an Hadis MA Muhammadiyah Kota Gorontalo, Wawancara, 9 November 2018.

${ }^{29}$ Fitri Salilama, Kepala MA Muhammadiyah Kota Gorontalo, Wawancara, 9 November 2018.

30 Aji Alfalah, Guru Fikih MA Muhammadiyah Kota Gorontalo, Wawancara, 9 November 2018.
} 
Implikasi TIK terhadap Prestasi Belajar Peserta Didik pada Kelompok Mata Pelajaran Agama di MA Muhammadiyah

Proses pembelajaran dengan model konvensional yang masih diterapkan oleh guru kelompok mata pelajaran pendidikan agama khususnya guru al-Qur'an Hadis dan SKI di MA Muhammadiyah Kota Gorontalo, seperti metode ceramah dan tanya jawab, kurang menarik bagi peserta didik dan cenderung berperilaku datang, duduk, dengar, diam, dan mengerjakan tugas hanya sekedar menjalankan perintah guru. Peserta didik kurang berminat bertanya apalagi mengemukakan pendapat tentang materi yang diberikan, bahkan peserta didik banyak yang tidak serius atau mengantuk. Hal ini tentu mengakibatkan prestasi belajar peserta didik yang tidak optimal.

Masih terdapat guru sebagai tenaga pendidik yang kurang kreatif memilih bentuk pengelolaan kelas yang potensial untuk meningkatkan prestasi belajar peserta didik. Guru Qur'an Hadis dan SKI di kelas misalnya masih banyak mentransfer pengetahuan kepada peserta didik. Pengelolaan kelas cenderung menggunakan metode ceramah untuk menyajikan materi serta minimnya pemanfaatan media teknologi yang mendukung kemudahan pemahaman peserta didik untuk meningkatkan prestasi belajar. Sementara itu di sisi lain guru fikih dan akidah akhlak justru sudah menggunakan media TIK dalam pembelajarannya namun kurang memberikan motivasi dan pemilihan media tidak didasarkan kepada gaya belajar peserta didik sehingga kurang optimal dalam pencapaian prestasi belajar pada mata pelajaran yang dibelajarkannya.

Penyederhanaan bentuk pengelolaan kelas tampaknya masih dijumpai di kelas X MA Muhammadiyah Kota Gorontalo dalam pembelajaran SKI dan al-Qur'an Hadis misalnya tidak selalu dipicu oleh rendahnya kreativitas guru, namun terkadang dipicu oleh karekteristik materi pelajarannya sendiri. Hasil penelusuran terhadap dokumen yang berkaitan dengan perangkat pembelajaran masih menunjukkan belum kreatifnya guru SKI dan al-Qur'an Hadis dalam merancang pembelajaran dan menerapkannya untuk meningkatkan prestasi belajar peserta didik.

Hasil pengamatan di lokasi penelitian menunjukkan bahwa objek konkret materi ajar tidak selalu dapat diamati secara langsung oleh peserta didik karena dalam pembelajaran SKI, guru tampak kurang menggunakan media berbasis teknologi informasi dan komunikasi yang memudahkan peserta didik menyimak materi ajar sehingga minimnya motivasi dan prestasi belajar.

Prestasi belajar yang dikemukakan di atas sebenarnya tidak berdiri sendiri, tetapi selalu berhubungan satu sama lain, bahkan ada dalam kebersamaan. Dalam proses pembelajaran di MA Muhammadiyah Kota Gorontalo saat ini, tipe hasil belajar kognitif lebih dominan jika dibandingkan dengan tipe hasil belajar afektif dan psikomotorik. Sekalipun demikian tidak berarti bidang afektif dan psikomotorik diabaikan sehingga tak perlu dilakukan penilaian.

Selama ini sebenarnya guru selalu diarahkannya untuk mencapai prestasi belajar peserta didik dari tiga ranah yang sudah menjadi ketentuan dalam pembelajaran karena prestasi belajar 
menurutnya adalah kecakapan nyata yang diukur berupa capaian pengetahuan, sikap dan keterampilan sebagai interaksi aktif antara subyek belajar dengan obyek belajar selama berlangsungnya proses pembelajaran untuk mencapai hasil belajar khususnya pada kelompok mata pelajaran pendidikan agama. ${ }^{31}$

Tipe hasil belajar afektif dan psikomotorik ada yang tampak pada saat proses pembelajaran berlangsung dan ada pula yang baru tampak setelah pembelajaran berlangsung. Hasil belajar kognitif misalnya terlihat dari kemampuan peserta didik menguasai materi pembelajaran, dan memahami konsep pembelajaran. Kompetensi afektif terlihat dari kemauan untuk menerima materi pelajaran dari guru, hasrat untuk bertanya kepada guru, kemauan untuk mempelajari bahan pelajaran lebih lanjut. Adapun kompetensi psikomotorik terlihat dari peserta didik mencatat bahan pelajaran secara baik dan sistematis, melakukan latihan diri dalam memecahkan masalah berdasarkan konsep bahan yang telah diperolehnya atau menggunakannya dalam praktek kehidupannya, akrab dan mau bergaul, mau berkomunikasi dengan guru dan bertanya atau meminta saran bagaimana mempelajari mata pelajaran yang diajarkannya.

Prestasi belajar yang dicapai peserta didik dapat dilihat dari kompetensi hasil belajar adalah kemampuan yang dimiliki oleh peserta didik dalam berbagai aspek (kognitif, afektif, dan psikomotor) setelah adanya proses belajar yang dilakukannya dalam pembelajaran. Guru tampak memiliki perbedaan dalam memberikan penyajian materi melalui media teknologi dan masih terdapat guru yang belum menggunakan media teknologi sehingga prestasi belajar masingmasing materi berbeda-beda.

Pernyataan kepala madrasah bahwa media berbasis TIK sebagai media pembelajaran merupakan salah satu bentuk dorongan dari luar diri peserta didik yang tampaknya mampu membangkitkan motivasinya dalam belajar, lebih cepat dalam memahami materi pelajaran, khususnya pada kelompok mata pelajaran pendidikan agama. Selain itu, peserta didik lebih menguasai materi sehingga mampu meningkatkan prestasi belajarnya. ${ }^{32}$

Hasil penelitian ini mengidentifikasi bahwa pembelajaran kelompok mata pelajaran pendidikan agama dengan menggunakan pemanfaatan TIK belum berimplikasi signifikan terhadap prestasi belajar. Pembelajaran fikih dan akidah akhlak lebih bermakna dan menarik bagi peserta didik karena guru telah menghadirkan masalahmasalah kontekstual dan realistik, yaitu masalah-masalah yang sudah dikenal, dekat dengan kehidupan sehari-hari peserta didik serta menggunakan strategi pembelajaran namun kurang diberikan motivasi dan tidak disesuaikan dengan gaya belajar. Akibatnya, prestasi dari kedua mata pelajaran tersebut tidak memberikan perbedaan yang

\footnotetext{
${ }^{31}$ Fitri Salilama, Kepala MA Muhammadiyah Kota Gorontalo, Wawancara, 9 November 2018.

${ }^{32}$ Fitri Salilama, Kepala MA Muhammadiyah Kota Gorontalo, Wawancara, 16 November 2018.
} 
signifikan baik ketika guru menggunakan media teknologi informasi maupun tidak menggunakan dalam pembelajaran.

Hal ini dibenarkan oleh guru fikih bahwa selama ini belum banyak memberikan motivasi atau dorongan kepada peserta didik dalam pembelajaran berbasis media TIK karena dianggapnya dengan adanya media sudah sekaligus memotivasi belajar peserta didik sehingga tidak diberikan lagi motivasi secara lisan atau perbuatan. Begitu pula dalam pemilihan media TIK tidak didasarkan kepada gaya belajar peserta didik dan lebih karena sesuai keinginan guru dalam menggunakan media TIK. ${ }^{33}$

Akan tetapi, sajian visual yang menarik sangat memudahkannya dalam proses pembelajaran karena kebetulan media yang digunakan guru fikih dan akidah akhlak cocok dengan gaya belajarnya. Pembelajaran dengan menggunakan media TIK tersebut telah menciptakan lingkungan belajar inovatif, sehingga merangsang berpikir dan berkreasi dalam memecahkan masalah namun belum memberikan implikasi yang berbeda ketika guru tidak menggunakan media teknologi tersebut sehingga prestasi belajarnya masih sama. ${ }^{34}$

Begitu pula dengan prestasi belajar peserta didik pada mata pelajaran fikih dan akidah akhlak yang menggunakan media teknologi informasi dan komunikasi dalam pembelajarannya dengan prestasi belajar peserta didik pada mata pelajaran Qur'an Hadis dan SKI yang tidak menggunakan media teknologi informasi dan komunikasi dalam pembelajarannya tidak diperoleh implikasi signifikan.

Dilihat dari soal yang diajukan oleh guru terhadap peserta didik diperoleh nilai capaian rata-rata 79,50 pada topik pertama di kelas XI mata pelajaran SKI dengan ketuntasan yang ditetapkan guru adalah 75. Capaian ini diperoleh dalam pembelajaran yang tidak menggunakan media teknologi informasi dan komunikasi namun dapat mencapai ketuntasan dalam prestasi belajarnya yakni di atas 75 .

Pengakuan dari peserta didik yang penulis wawancarai menjelaskan adanya nilai hasil belajar pada pertemuan pertama sudah mencapai KKM walaupun diajarkan dengan tidak menggunakan media TIK oleh guru SKI disebabkan oleh guru selalu memberikan motivasi dengan memberikan contoh perjuangan Rasulullah dalam menuntut ilmu sehingga membuat peserta didik terdorong untuk giat belajar. ${ }^{35}$ Guru SKI mengakui sejarah terkadang membuat peserta didik bosan namun ketika disajikan dengan cerita yang menarik diiringi dengan dorongan yang membuat peserta didik termotivasi

33 Aji Alfalah, Guru Fikih MA Muhammadiyah Kota Gorontalo, Wawancara, 16 November 2018.

${ }^{34}$ Intan Putri Pratama, Peserta didik MA Muhammadiyah Kota Gorontalo, Wawancara, 16 November 2018.

${ }^{35}$ Herianto Antonio, Peserta didik MA Muhammadiyah Kota Gorontalo, Wawancara, 16 November 2018. 
untuk belajar sehingga kendati tidak digunakan TIK namun hasrat dan kemauan belajar tinggi membuat prestasinya meningkat pula. ${ }^{36}$

Sementara itu guru akidah akhlak dan fikih di kelas XI dalam pembelajarannya justru banyak menggunakan media teknologi informasi dan komunikasi berupa power point dan media digital lainnya namun diperoleh data prestasi belajar peserta didik tidak terdapat perbedaan signifikan dengan yang diperoleh guru SKI.

KKM yang ditetapkan oleh guru akidah akhlak pada topik pertama yaitu 72 sudah dicapai oleh peserta didik namun tidak berbeda jauh dengan yang diperoleh peserta didik pada mata pelajaran SKI sehingga belum berimplikasi positif terkait penggunaan media TIK dalam pembelajaran akidah akhlak. Guru terkadang tidak memberikan motivasi kepada peserta didik yang kurang terlibat dalam pemanfaatan media TIK dalam kegiatan kelompok.

Penjelasan dari peserta didik terkait dengan perolehan nilai hasil belajar mata pelajaran akidah akhlak yang tidak jauh berbeda dengan mata pelajaran SKI pada pertemuan pertama di atas adalah disebabkan ketika pembelajaran dengan menggunakan media TIK tersebut terkadang tidak sesuai dengan gaya belajarnya dan guru tidak memberikan motivasi dengan kata-kata atau perbuatan kepada peserta didik karena sudah diberikan TIK. ${ }^{37}$

Akan tetapi kaitannya dengan pembelajaran kelompok mata pelajaran pendidikan agama, guru fikih dan akidah akhlak tampak telah menguasai perangkat lunak yang mendukung bidang ajarnya seperti MS.Word, MS Power Point, MS.Excel atau program aplikasi lainnya. Hal ini berbeda dengan guru SKI dan Qur'an Hadis yang belum menguasai sepenuhnya perangkat dimaksud secara mahir sehingga dalam pembelajaran sering tidak menggunakan media teknologi dalam membelajarkan peserta didiknya.

Guru akidah akhlak dan fikih tampak menyiapkan sendiri bahan pembelajaran berbasis komputer. Pembelajaran berbasis media TIK menunjukkan bahwa kelompok peserta didik yang memiliki kemampuan dasar relatif baik, lebih terlihat pengembangan daya kognitif, afektif, dan psikomotoriknya. Walaupun demikian peran pendidik belum sepenuhnya dapat digantikan oleh teknologi, dalam arti elearning berperan sebagai suplemen sehingga wajar jika kemudian prestasi belajar tidak berbanding lurus dengan kemampuan guru dalam penggunaan media teknologi dimaksud.

Penelusuran penulis terkait penggunaan TIK dalam pembelajaran akidah akhlak dan fikih karena guru pada kedua mata pelajaran tersebut sudah tersertifikasi sedangkan guru Qur'an Hadis dan SKI belum tersertifikasi sehingga kemampuan di bidang TIK juga berbeda.

\footnotetext{
${ }^{36}$ Abdullah Isima, Guru SKI MA Muhammadiyah Kota Gorontalo, Wawancara, 16 November 2018.

${ }^{37}$ Arung Pasrima, Peserta didik MA Muhammadiyah Kota Gorontalo, Wawancara, 16 November 2018.
} 
Dari data yang diperoleh terdapat 9 orang guru yang telah tersertifikasi dari bidang studi umum (kimia, biologi, fisika, sejarah, dan bahasa Indonesia) dan bidang studi pendidikan agama (fikih dan akidah akhlak). Pelaksanaannya berbeda baik dari segi tahun yakni dari tahun 2007 sampai dengan tahun 2012 maupun lembaga yang ditunjuk sebagai pelaksananya yakni dari IAIN Sultan Amai Gorontalo dan Universitas Negeri Gorontalo.

Guru banyak yang telah mengikuti kegiatan pelatihan atau seminar yang diadakan oleh instansi terkait hingga ke tingkat provinsi maupun nasional yang dibuktikan dengan kemampuan mereka yang lebih baik sehingga dengan sertifikat yang diperolehnya mampu menunjang kinerjanya dalam melaksanakan tugas dan tanggungjawabnya sebagai guru yang profesional. ${ }^{38}$

Dalam proses pembelajaran, guru fikih dan akidah akhlak tampaknya lebih banyak memanfaatkan teknologi informasi, seperti untuk menyampaikan materi, media pembelajaran, serta memanfaatkan teknologi informasi pada peserta didik untuk mencari tugas. Teknologi informasi juga tampaknya digunakan oleh peserta didik untuk mengerjakan tugas seperti mengetik tugas di microsoft word, membuat presentasi power point, serta mencari sumber belajar dengan internet.

Sebagaimana ditegaskan oleh informan bahwa penggunaan teknologi informasi belum memberikan dampak yang luas terhadap prestasi belajar peserta didik khususnya dalam kelompok mata pelajaran pendidikan agama karena disadari TIK terkadang mempunyai dampak positif dan negatif sehingga terkadang disalahgunakan oleh peserta didik bukan untuk mencari tugas namun lebih banyak ${ }_{39}$ sebagai hiburan atau tidak selektif dalam penggunaannya. ${ }^{39}$

Hal tersebut diakui oleh orang tua peserta didik bahwa tersedianya berbagai informasi, aplikasi dan hiburan, menuntut pengguna TIK khususnya peserta didik dengan pengawasan orang tua di rumah agar lebih selektif dan bijak dalam menggunakannya. Terlebih penggunaan teknologi informasi pada peserta didik saat ini yang kurang kontrol dari orang tua karena sibuk bekerja di rumah atau di luar rumah sehingga lalai mengawasi penggunaan HP anaknya apalagi banyak dijadikan alasan adalah mengerjakan tugas padahal kenyataannya hanya membuka situs yang tidak layak dikonsumsi. ${ }^{40}$

Apabila penggunaan teknologi informasi tepat guna seperti untuk mencari sumber belajar atau referensi mata pelajaran dari internet, mencari buku elektronik serta digunakan untuk berdiskusi mengenai materi pelajaran, inilah yang membuat peserta didik

\footnotetext{
${ }^{38}$ Husman, Guru Bahasa Indonesia MA Muhammadiyah Kota Gorontalo, Wawancara, 28 Desember 2018.

39 Aji Alfalah, Guru Fikih MA Muhammadiyah Kota Gorontalo, Wawancara, 23 Desember 2018.

${ }^{40}$ Zulkarnaen, Orang Tua Peserta Didik di MA Muhammadiyah Kota Gorontalo, Wawancara, 23 Desember 2018.
} 
menguasai materi pelajaran dengan sangat baik yang berdampak pada meningkatnya prestasi belajarnya. Sebaliknya apabila penggunaan teknologi informasi hanya untuk mencari hiburan seperti bermain game online ataupun offline, mencari hal-hal berbau pornografi, dan chatting saat pelajaran berlangsung telah menyebabkan peserta didik banyak mengalami kerugian.

Kerugian yang diakibatkan kesalahan dalam penggunaan TIK baik dalam pembelajaran maupun di luar atau di rumah sebagaimana terpantau oleh penulis selama berada di lingkungan madrasah ini seperti terbuangnya waktu untuk belajar, tidak pahamnya peserta didik akan materi yang diajarkan oleh guru karena asyik bermain game dan chatting saat pelajaran berlangsung, serta ilmu dan wawasan peserta didik tidak bertambah. Hal tersebut menyebabkan prestasi belajar peserta didik kurang optimal atau tidak berbeda dengan pembelajaran yang tidak menggunakan TIK.

\section{Kesimpulan}

Realitas TIK dalam pembelajaran pada kelompok mata pelajaran pendidikan agama yaitu fikih dan akidah akhlak menggunakan PowerPoint dan bahan ajar digital. Pembuatan media pembelajaran berbasis TIK dengan topik-topik yang terdapat pada silabus dan RPP dengan memperhatikan nilai standar kompetensi. Adapun guru Qur'an Hadis dan SKI masih belum banyak menggunakan TIK dalam pembelajarannya namun banyak memberikan motivasi belajar kepada peserta didik melalui penyajian materi.

Implikasi TIK terhadap prestasi belajar peserta didik pada kelompok mata pelajaran pendidikan agama khususnya dalam pembelajaran fikih dan akidah akhlak yang menggunakan PowerPoint dan bahan ajar digital belum memberikan dampak yang positif terhadap prestasi belajar peserta didik karena kurang disesuaikan dengan gaya belajar peserta didik dan tidak dibarengi dengan pemberian motivasi dari guru serta terkadang peserta didik menyalahgunakan penggunaan TIK untuk sesuatu yang tidak diharapkan oleh guru. Sedangkan guru Qur'an Hadis dan SKI kendati kurang menggunakan TIK dalam pembelajaran namun diimbangi dengan pemberian motivasi ketika menyajikan materi sehingga nilai hasil belajarnya mencapai KKM sebagaimana pada mata pelajaran fikih dan akidah akhlak. Kemudahan belajar sudah diperoleh pada guru fikih dan akidah akhlak melalui penggunaan TIK dalam pembelajarannya.

\section{Daftar Pustaka}

Arsyad, Azhar. Media Pembelajaran, Jakarta: Rajawali Press, 2017.

Asnawir, dan M. Basyirudin Usman. Media Pembelajaran, Cet. 1; Jakarta: Ciputat Pers, 2002. 
Bau, Rommy. "Kontribusi Dunia Maya dalam Meningkatkan Prestasi Belajar di MAN Model Gorontalo" Makassar: UIN Alauddin, 2014.

Darsono, Max. dkk., Belajar dan Pembelajaran, Semarang: IKIP Semarang Press, 2000

Departemen Pendidikan Nasional, Penilaian Hasil Belajar. Jakarta: Direktorat Tenaga Kependidikan Direktorat Jenderal Peningkatan Mutu Pendidik dan Tenaga Kependidikan, 2008.

Djamarah, Syaiful Bahri dan Aswan Zain, Guru dan Anak Didik dalam Interaksi Edukatif, Jakarta: Rineka Cipta, 2000.

Elang, Krisnadi. Rancangan Materi Pembelajaran Berbasis TIK. Makalah disajikan dalam Workshop Pengembangan Materi Pembelajaran Berbasis TIK di FMIPA UNY pada tanggal 6 Agustus 2009

Hamalik, Oemar. Kurikulum dan Pembelajaran, Jakarta: Bumi Aksara, 2001.

-------, Media Pendidikan, Bandung: Aditya Bakti, 1989.

Haryanto, Edy. Teknologi Informasi dan Komunikasi: Konsep dan Perkembangannya. Pemanfaatan Teknologi Informasi dan Komunikasi Sebagai Media Pembelajaran. 2008.

Isjoni dan Arif Ismail, Pembelajaran Virtual; Perpaduan IndonesiaMalaysia, Cet. 1; Yogyakarta: Pustaka Pelajar, 2008.

Juju, Dominikus dan Feri Sulianta, Hitam Putih Facebook. Jakarta: Elex Media, 2005.

Keputusan Menteri Pendidikan dan Kebudayaan Nomor 65 Tahun 2013 tentang Standar Proses Pendidikan Dasar dan Menengah.

Komala, Lukiati, Ilmu Komunikasi, Perpektif, Proses, dan Konteks. Bandung: Widya Padjajaran, 2009.

Krisnadi, Elang, Rancangan Materi Pembelajaran Berbasis ICT. disajikan dalam Workshop Pengembangan Materi Pembelajaran Berbasis ICT di FMIPA UNY pada tanggal 6 Agustus 2009.

Maslow, Abraham. Motivasi dan Kepribadian, Jakarta: Lembaga Manajemen, 2004.

Mulyasa, E., Menjadi Guru Profesional Menciptakan Pembelajaran Kreatif dan Menyenangkan. Cet. 2; Bandung: Remaja Rosdakarya, 2005.

Munir, Kurikulum Berbasis Teknologi Informasi dan Komunikasi. Bandung: Alfabeta, 2008.

Oetomo, Budi Sutedjo Dharma, e-Education, Konsep, Teknologi dan Aplikasi Internet Pendidikan. Yogyakarta: Andi Yogyakarta, 2002.

192 | Sarton Abdullah, Arten Mobonggi, Najamuddin Petta Solong, Muh. Arif 
Poerwanti, Endang. dan Nur Widodo, Perkembangan Peserta Didik. Malang: Universitas Muhammadiyah Malang Pers, 2002.

Qonita, Alya. Kamus Bahas Indonesia Untuk Pendidikan Dasar, Jakarta: Indah Jaya Adipratama, 2009.

Rochaety, Eti. dan Pontjorini Rahayuningsih Prima Gusti Yanti, Sistem Informasi Manajemen Pendidikan, Cet. 4; Jakarta: Bumi Aksara, 2009.

Sadiman, Arief S., Media Pendidikan; Pengertian, Pengembangan, dan Pemanfaatannya, Jakarta: Grafindo Persada, 2005.

Sadiman, Arief S., Media Pendidikan, Jakarta: Pustaka Pelajar, 2005.

Sagala, Saiful. Manajemen Strategik dalam Peningkatan Mutu Pendidikan, Cet. 2; Bandung: AlFabeta, 2007.

Suwandi, Model-Model Asesmen dalam Pembelajaran. Surakarta: Yuma Pustaka, 2011.

Tu'u, Tulus. Peran Disiplin pada Perilaku dan Prestasi Peserta Didik. Jakarta: Grasindo, 2004.

Undang-Undang Republik Indonesia Nomor 20 tahun 2003 tentang Sistem Pendidikan Nasional, Bandung: Citra Umbara, 2003.

Warsita, Bambang, Pendidikan Jarak Jauh; Perancangan, Pengembangan, Implementasi, dan evaluasi Diklat. Bandung: Remaja Rosdakarya, 2001.

Wuryani, Sri Estuti. Psikologi Pendidikan. Jakarta: Gramedia Widiasarana, 2002. 